症例

急性虫垂炎として発症した虫垂好銀性カルチノイドの 1 例 フジヤマ病院外科

佐野佳彦山川知洋佐々木学

急性虫垂炎で発症し, 病理学的検索で虫垂好銀性カルチノイドと診断した症例を経験 した．症例は36歳女性．下腹部痛を主訴に入院した．右下腹部に筋性防御を伴う圧痛を 認めたが, 入院 2 日目に理学的所見, 炎症所見ともに増悪したため, 急性虫垂炎として, 虫垂切除術を施行した。病理組織学的には, 虫垂粘膜下層を主座に, 球状で, 粗大なク ロマチンを有し, 比較的均一な核を有する細胞のシート状, 胞巣状, 一部索状の增生が みられ, 腫煌細胞は chromogranin A 染色陽性, Grimelius 染色陽性, Fontana-Masson 染色陰性であり，虫垂好銀性カルチノイドと診断した。組織学的に断端陽性であったた め, 55日後に追加切除 (回盲部切除) を行ったが, 摘出標本に腫瘍細胞はみられなかっ た. 術後 1 年 4 カ月の現在再発の徴候はみられない. 虫垂好銀性カルチノイドは極めて 稀であるため, 若干の文献的考察を加えて報告する。

索引用語 : 虫垂, カルチノイド腫瘍, 好銀性カルチノイド

\section{鍺 言}

カルチノイド腫瘍は神経内分泌細胞から発生する腫 瘍であり, 異型度の低い組織像で発育が䌅徐で, 通常 の癌と異なる特徵を有する腫瘍とされている，本腫瘍 は74\%が消化管に発生し1, 虫垂カルチノイドは,わが 国では直腸, 十二指腸, 胃に次ぐ頻度で2), 比較的稀で ある.WHOの分類では㖺銀性カルチノイド（argentaffin carcinoid), 好銀性カルチノイド (argyrophil carcinoid), 杯細胞カルチノイド (goblet cell carcinoid)の三亚型に分類されている゙かが, 本邦報告例 の大半が杯細胞カルチノイドと診断されており, 今回 われわれが経験した好銀性カルチノイドは非常に稀と 考えられるので，文献的考察を加えて報告する。

$$
\text { 症例 }
$$

患者：36歳, 女性.

主訴: 腹痛, 哣気, 嘔吐.

家族歴：特記すべきことなし.

既往歴: 卵巣癌にて平成 15 年 6 月, 他院にて左卵巣 摘出術施行されている.

現病歴：平成15年 9 月24日 $0 ： 00$ 頃から, 上腹部痛,

2005 年 1 月 28 日受付 2005 年 4 月28日採用

〈所属施設住所〉

テ418-0105 富士宮市原683-1
嘔気, 嘔吐が出現. 朝, 救急センター受診し鎮痛薬を 投与されたが軽快せず。その後下腹部痛となり，8： 33救急車で当院を受診し，入院となった。

入院時現症: 身長 $157 \mathrm{~cm}$, 体重 $60 \mathrm{~kg}$, 体温 $38.4^{\circ} \mathrm{C}$. 血圧 $142 / 60 \mathrm{mmHg}$, 脈拍 96 回/分. 右下腹部に軽度の筋 性防御を伴う圧痛あり, Blumberg 徵候は認めず.

入院時検査成績：WBC $9,000 / \mathrm{mm}^{3}$, CRP $1.03 \mathrm{mg} /$ $\mathrm{dl}$ と, 軽度の炎症所見を認める以外，特記すべき所見 はなかった。

入院時腹部単純 $\mathrm{X}$ 線写真：下腹部に軽度の小腸㹡 張を認めた。

入院時腹部超音波所見：消化管ガスのため虫垂の同 定は困難であった。

入院時腹部 $\mathbf{C T}$ ：右下腹部，盲腸の左側に接して肥 厚した虫垂と思われる造影効果のある管状構造物を認 めた（図 1)，腹腔内液体貯留はみられなかった。

入院後経過：急性虫垂炎と診断し，抗生物質投与に て経過を観察していたが，腹痛持続し，翌日になり右 下腹部を中心に筋性防御と Blumberg 徵候を伴う強 い圧痛が認められた。また血液検查でも WBC 18,800 / $\mathrm{mm}^{3}, \mathrm{CRP} 30.0 \mathrm{mg} / \mathrm{dl}$ と炎症所見が増悪したため, 手 術を施行した。

手術所見：仰臥位腰椎麻酔下にて手術を行った，右 下腹部傍腹直筋切開で開腹すると, 虫垂周囲に膿汁が 


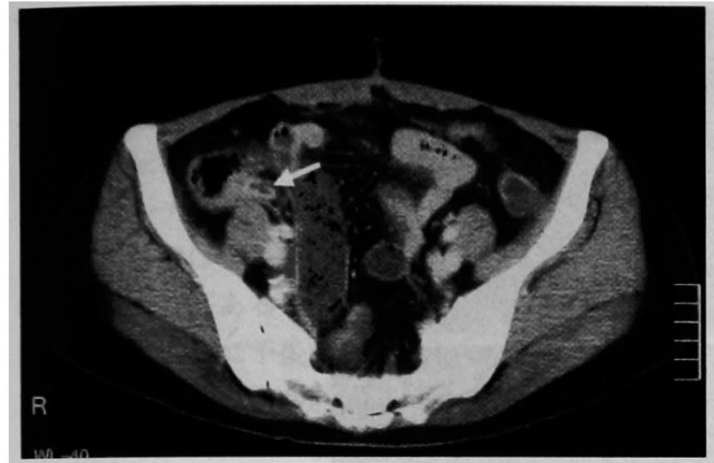

图 1 入院時腹部 CT 検査：盲腸の左側に接して肥厚し た虫垂と思われる管状構造物（矢印）を認める.

町留しており，虫垂は硬く肥厚していた，また虫垂根 部から盲腸にかけ小豆大の腫瘤が触知され，これを含 めて虫垂切除術を施行した。

切除標本肉眼所見：虫垂は根部に $10 \mathrm{~mm}$ 大の腫瘤が みられ，先端部は白色調に腫脹し，体部は硬化してい た（図 2 )。なお，手術操作により虫垂は中央部で分断 されている。

病理組織学的所見 : 虫垂根部〜盲腸に結節状腫㨨が みられ，粘膜下層を主座に，球状で，粗大なクロマチ ンを有し，比較的均一な核を有する細胞のシート状， 胞巣状, 一部索状の增生がみられ(図 $3 \mathrm{a}$ )，一部は粘 膜に露出し，また浆膜，腸間膜へ浸潤していた．固有 虫垂では，粘膜，粘膜下層の炎症性細胞浸潤，腹膜炎 の像がみられた。腫場紐胞は chromogranin A 染色陽 性, Grimerius (Argyrophil) 染色陽性であったが (図 3 b, c), Fontana-Masson (Argentaffin) 染色は陰 性であった。また synaptophysin 染色はごく少数陽性 であった(図 $3 \mathrm{~d}$ )。杯細胞あるいは印環細胞類似の細 胞はみられなかったことから，虫垂好銀性カルチノイ ドと診断した。 また大腸癌取扱い規約に準じると媣達 度 si (腸間膜), ly3, voであり，断端陽性であった。

この結果を受けて腫瘍マーカー(CEA，CA19-9)を 測定したがいずれも陰性であった．術後創感染を併発 したため連日創処置を行い, 感染が軽快するのを待っ て術後55日目に再手術を行った。

再手術時所見：全身麻酷下に下腹部正中切開にて開 腹し, 回盲部切除術および大腸癌取扱い規約による D2 郭清を施行した。

切除標本中には組織学的に腫場細胞の遺残やリンパ 節転移は認められなかった。

患者は術後順調に経過し, 第17病日に軽快退院した。

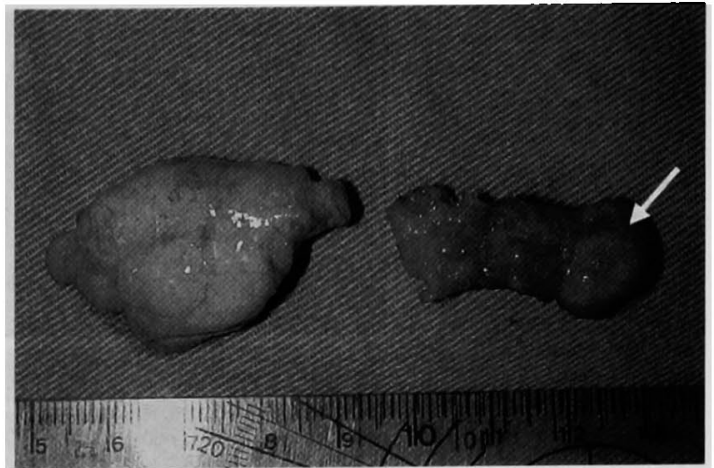

図 2 切除標本：虫垂根部に $10 \mathrm{~mm}$ 大の腫瘤 (矢印) を認 める.

術後 1 年 4 力月の現在, 再発の徴候を認めていない.

$$
\text { 考察 }
$$

「カルチノイド」という名称は1907年 Oberndorfer") がドイツ病理学会で“Karzinoid”として命名したのが 最初とされている. 彼はカルチノイドは生物学的にも 臨床経過においても腺癌よりも良性なる腫場であるこ とを強調した，現在ではこの腫瘍は神経内分泌細胞 (neuroendocrine cell) から発生した腫瘍と考えられ ている. 部位による頻度はModlinら”によれば，消化 管 $73.7 \%$, 呼吸器 $25.1 \%$ と報告されている。腸粘膜細 胞には約 1〜2\%の神経内分泌細胞が存在するといわ れており

(29\%), 虫垂 (19\%), 直腸 (13\%) の順であるが6), わが国では, 直腸, 十二指腸, 胃, 虫垂の順とされて いる2!. 虫垂カルチノイドは虫垂切除例中 $0.3 \sim 0.9 \%$ にみられるとされク，稀な疾患である．女性に多く，平 均年齢は 42.2 歳である5).

カルチノイド腫演の分類は，WHOの分類では(1)嫩 銀性カルチノイド (argentaffin carcinoid)，(2)好銀性 カルチノイド (argyrophil carcinoid), (3)杯細胞カル チノイド (goblet cell carcinoid)に分類され ${ }^{31}$, Morson $5^{8)}$, (1) classical argentaffin carcinoid, (2) nonargentaffin carcinoid, (3) mucinous, goblet cell, adenocarcinoid に分類している。しかし岩下采によれ ば杯細胞カルチノイドの生物学的態度は従来考えられ ている以上に十分な悪性性格を示し，本腫瘍をカルチ ノイドの 1 variant とするには組織像の面でも予後の

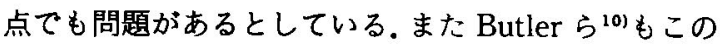
腫瑒 (adenocarcinoid or goblet cell carcinoid) は古 典的なカルチノイドより攻揧的な性格を有しており， 異なった外科的アプローチが必要としている。 


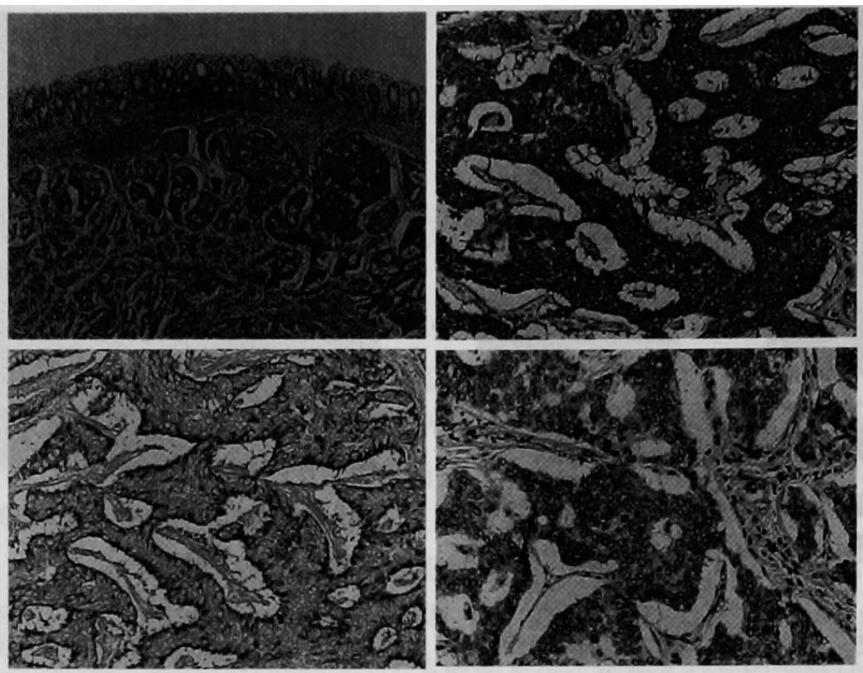

図 3 病理組織学的所見

a H-E 染色 $(\times 4)$ ：粘膜下層を主座として腫疸紐胞の増殖が見 られる.

b chromogranin A 染色 $(\times 20)$ : 陽性.

c Grimerius 染色 $(\times 20)$ : 陽性.

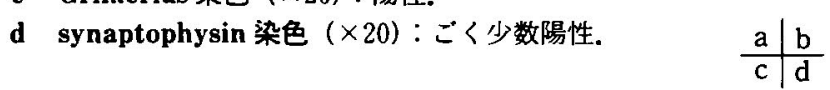

本症例は Grimelius (Argyrophil) 陽性, FontanaMasson (Argentaffin) 陰性で, 杯細胞ないしは印珢 細胞類似の細胞がみられなかったことから，上記分類 (2)の，好銀性カルチノイドと診断した。

本邦では虫垂カルチノイドのうち杯細胞カルチノイ ドの頻度が高く, 2004年の佐藤ら"1の集計では61例で あったのに対し，われわれが検索した限りでは，好銀 性カルチノイドは曽ケ端ら ${ }^{22}$ が報告した1例があるの みで，極めて稀であると考えられる。

虫垂カルチノイドは，術前に診断することはきわめ て困難である。急性虫垂炎, 回盲部腫瘍,イレウスな どの術前診断のもとに手術され，切除標本にて発見さ れることが大部分である. Moertel らかの報告による と,137例の虫垂カルチノイド切除例のうち術前診断さ れたのは 2 例のみである. 本邦においても佐藤らいの 集計によれば，術前に確定診断された症例は 1 例もな かった．実際的な対処としては，切除虫垂の注意深い 肉眼的検索を励行することと, 腫瘍が疑われれば術中 迅速病理診断を行うこと, 切除虫垂は全例病理組織検 查をすべきであると考える．本症例では術中肉眼的に 腫瘍性病変が疑われたが, 当院では常勤の病理医がお らず迅速病理診断が不可能であったため, 術後の確定
診断となった。

治療方針のなかで最も重要な点は，腫瘍の大きさで あるといわれている. Moertel ら゙は150例の虫垂カル チノイド症例の追跡調査結果から, 最大径 $2 \mathrm{~cm}$ 末満 のものには 1 例も転移は認められなかったが, $2 \mathrm{~cm}$ を超える腫瘍23例中の 7 例に転移が認められ，とくに $3 \mathrm{~cm}$ を超えるものには $44 \%$ に転移が認められたと報 告している. Stinner $ら^{13}$ は, $1 \mathrm{~cm}$ 以下の虫垂カルチ ノイドは転移は稀で虫垂切除術のみでよく，2 cm 以

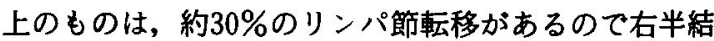
腸切除術が必要としている，最近の報告では，右半結 腸切除術の適応として, (1) $2 \mathrm{~cm}$ 以上の病変, (2)虫垂間 膜進展, (3)虫垂根部にあり断端陽性あるいは盲腸への 進展が見られるもの，(4)悪性度の高いカルチノイド， (5)杯細胞カルチノイド,のいずれかとしている14.しか しVarisco ら ${ }^{15}$ の検討では，杯細胞カルチノイドの転 移のリスクは腫瑒の深達度より生化学的, 組織学的特 徵に関連があるので, 限局した病変では, 盲腸浸潤が なく低悪性度の場合は虫垂切除術のみでよいとしてお ク，現在でも議論のあるところである.

本症例においては，切除断端が陽性であり，かつリ ンパ管侵㜞が認められたためリンパ節郭清を含む追加 
切除を行った。

なお，本症例ではほほ同時期に贸巣癌の手術既往が

あるがこれは組織学的に粘液性胞腺癌と診断され

ており，転移ではないと考えている。

虫垂カルチノイドの予後は一般的に良好て, Sandor $ら^{16)}$ の集計では 5 生率は $85.9 \%$ で消化管カルチノイド の中で最も良好あるとされている. しかし杯細胞カル チノイドは一般に予後が悪く10)，これらも念頭におい て治療にあたることが肝要であると考えている。

結語

急性虫垂炎に対して虫垂切除術を行うに当たって は,常に本疾患を含む腫瘍性病変の存在を念頭に置き， かつ全例に病理学的検索を行うことが重要であると考 える。

\section{謝 辞}

稿を終えるにあたり，御指導を賜りました和歌山県立医 科大学病理学第 2 , 中村靖司先生に深謝致します.

\section{文献}

1) Modlin IMI, Sandor A: An analysis of 8305 cases of carcinoid tumors. Cancer $79: \$ 13-$ 829, 1997

2）渡辺英伸：腸のカルチノイド腫瘍。胃と腸 24 ： $853-857,1989$

3) Moertel CG, Weiland LH, Nagorney DM, et al : Carcinoid tumour of the appendix : Treatment and prognosis. N Engl J Med 317 : 1699-1701, 1987

4) Oberndorfer S: Karzinoide Tumoren des Dunndarms. Frankf Zschr Pathol $1: 426-430,1907$

5) Sandor A, Modlin IM : A retrospective analysis of 1570 appendiceal carcinoids. Am J Gastroenterol $93: 422-428,1998$

6) Lauffer JM, Zhang T, Modlin IM : Review article : current status of gastrointestinal carcinoids. Aliment Pharmacol Ther 13:271-
287, 1999

7) Goede $\mathrm{AC}$, Caplin $\mathrm{ME}$, Winslet $\mathrm{MC}$ : Carcinoid tumour of the appendix. Br J Surg $90: 1317-$ 1322,2003

8) Morson BC, Dawson IMP, Day DW, et al : Benign and malignant epithelial tumours. Tumours of the appendix. Morson \& Dawson's Gastrointestinal Pathology, Blackwell Scientific Publishers, Oxford, 1990, p412-417

9）岩下明徳：虫垂の杯細胞カルチノイド一杯細胞カ ルチノイドは本当にカルチノイドの 1 variant 加?一。外科 $58: 1366-1370,1996$

10) Butler JA, Houshiar A, Lin F, et al : Goblet cell carcinoid of the appendix. Am J Surg 168: 685 $-687,1994$

11）佐藤公司，所 忠男，塩崎 均：腸閉塞症をきた した虫垂杯細胞カルチノイドの 1 例. 日臨外会誌 $65: 449-453,2004$

12) 曾ヶ端克哉, 水島康博, 川本雅樹他：虫垂カルチ ノイドの1例. 臨と研 $80: 317-320,2003$

13) Stinner $B$, Kisker $O$, Zielke A, et al : Surgical management for carcinoid tumors of small bowel, appendix, colon, and rectum. World J Surg $20: 183-188,1996$

14) Goede AC, Caplin ME, Winslet MC : Carcinoid tumour of the appendix. Br J Surg $90: 1317-$ 1322, 2003

15) Varisco B, McAlvin B, Dias J, et al : Adenocarcinoid of the appendix : is right hemicolectomy necessary? A meta-analysis of retrospective chart reviews. Am Surg $70: 593-599,2004$

16) Sandor A, Modlin I.M : A retrospective analysis of 1570 appendiceal carcinoids. Am J Gas. troenterol $93: 422-428,1998$ 


\title{
A CASE OF ARGYROPHIL CARCINOID OF THE APPENDIX PRESENTED WITH ACUTE APPENDICITIS
}

\author{
Yoshihiko SANO, Tomohiro YAMAKAWA and Manabu SASAKI \\ Department of Surgery, Fujiyama Hospital
}

We experienced a case of argyrophil carcinoid of the appendix in 36-year-old woman who was admitted to the hospital because of lower abdominal pain, nausea and vomitting. We performed appendectomy next day under the diagnosis of acute appendicitis. Resected appendix was whitish, hard and swollen, and histological examination revealed proliferation of tumor cells mainly in the submucosal layer of the appendix. The tumor cells were positive with Grimelius and chromogranin A stain, and negative with Fontana-Masson stain. Therefore, we diagnosed the case as argyrophil carcinoid of the appendix. Because of the positive surgical margin, ileocecal resection with lymphadenectomy was performed 55 days after the initial operation. There were no tumor cells microscopically in the resected specimen. There is no signs of recurrene in one year and 4 months since the operation. To our knowledge, argyrophil carcinoid of the appendix is very rare in Japan. Here, we report this case with a review of the literature. 